\title{
TEXTO\& CONIEXTo
LAFERNAGFM
}

TEXT \& CONTEXT NURSING TEXTO \& CONTEXTO ENFERMERÍA

\section{CHILDHOOD OBESITY IN THE PERCEPTION OF CHILDREN, FAMILIES AND HEALTH AND EDUCATION PROFESSIONALS}

\author{
Maria Aparecida Baggio' 1 (D) \\ Karine Ribeiro Alves ${ }^{2}$ (b) \\ Raiana Friedrich Cavalheiro 2 (D) \\ Laurinda de Matias ${ }^{2}$ (B) \\ Aline Renata Hirano' 1 \\ Gicelle Galvan Machineski ${ }^{3}$ (D) \\ Sebastião Caldeira ${ }^{1}$ (D)
}

'Universidade Estadual do Oeste do Paraná, Programa de Pós-Graduação em Saúde Pública em Região de Fronteira. Cascavel, Paraná, Brasil. 2Universidade Estadual do Oeste do Paraná. Cascavel, Paraná, Brasil. ${ }^{3}$ Universidade Estadual do Oeste do Paraná, Programa de Pós-Graduação em Biociências. Cascavel, Paraná, Brasil.

\begin{abstract}
Objective: to understand the perspective of children, families and health and education professionals about childhood obesity.

Method: a qualitative research study with the participation of 13 children, 12 family members, seven health professionals in primary care and seven education professionals, all linked to the Health at School Program. Data was collected through semi-structured interviews, using recreational resources and applying a scale of silhouettes with children, during the period from April 2017 to March 2018. The analysis was based on the assumptions of thematic content analysis.

Results: three categories were identified: Multifactoriality of childhood obesity; Body image by the child, by family members and bullying at school; Perspectives and actions associated with childhood obesity. For the study participants, childhood obesity is conditioned by overeating, with a low nutritional value, in addition to insufficient physical activity. They also understand that the actions to combat obesity proved to be incipient or insufficient. For children, obesity implies dissatisfaction with body image and bullying at school.

Conclusion: according to the perspective of the participants, there is a need for integrated actions between health and education professionals, including children and family members, to prevent and combat childhood obesity; in addition to governmental actions to strengthen public policies that consider health promotion and prevention of harms to the child population.
\end{abstract}

DESCRIPTORS: Children's health. Family. Pediatric obesity. School health services. Education. 


\section{OBESIDADE INFANTIL NA PERCEPÇÃO DE CRIANÇAS, FAMILIARES E PROFISSIONAIS DE SAÚDE E DE EDUCAÇÃO}

\section{RESUMO}

Objetivo: compreender a perspectiva de crianças, familiares e profissionais da saúde e da educação acerca da obesidade infantil.

Método: pesquisa qualitativa com participação de 13 crianças, 12 familiares, sete profissionais da saúde da atenção básica e sete profissionais da educação, todos vinculados ao Programa Saúde na Escola. A coleta de dados foi por entrevista semiestruturada, utilização de recursos lúdicos e aplicação de escala de silhuetas com crianças, no período de abril de 2017 a março de 2018. A análise foi fundamentada nos pressupostos da análise temática de conteúdo.

Resultados: foram identificadas três categorias: Multifatorialidade da obesidade na infância; Imagem corporal pela criança, por familiares e o bullying na escola; Perspectivas e ações associadas à obesidade infantil. Para os participantes do estudo a obesidade infantil é condicionada por alimentação excessiva, com baixo valor nutricional, além da prática insuficiente de atividade física. Entendem, ainda, que as ações para combater a obesidade se mostraram incipientes ou insuficientes. Para as crianças a obesidade implica na insatisfação com a imagem corporal e no bullying escolar.

Conclusão: conforme a perspectiva dos participantes, aponta-se para a a necessidade de ações integradas entre profissionais da saúde e da educação, que incluam crianças e familiares, para prevenção e combate da obesidade infantil; além de ações governamentais para o fortalecimento das políticas públicas que consideram a promoção da saúde e prevenção de agravos à população infantil.

DESCRITORES: Saúde da criança. Família. Obesidade pediátrica. Serviços de saúde escolar. Educação.

\section{LA OBESIDAD INFANTIL DESDE LA ÓPTICA DE LOS NIÑOS, FAMILIARES Y PROFESIONALES DE LA SALUD Y LA EDUCACIÓN}

\section{RESUMEN}

Objetivo: comprender la perspectiva de los niños, familiares y profesionales de la salud y la educación sobre la obesidad infantil.

Método: investigación cualitativa con la participación de 13 niños, 12 familiares, siete profesionales de la salud de atención primaria y siete profesionales de la educación, todos vinculados al Programa Salud en la Escuela. La recolección de datos se realizó mediante entrevistas semiestructuradas, mediante la utilización de recursos lúdicos y la aplicación de una escala de siluetas con niños, de abril de 2017 a marzo de 2018. El análisis se basó en los supuestos del análisis de contenido temático.

Resultados: se identificaron tres categorías: Multifactorialidad de la obesidad infantil; Imagen corporal desde la óptica del niño, los familiares y el bullying infantil; Perspectivas y acciones asociadas a la obesidad infantil. Para los participantes del estudio, la obesidad infantil está condicionada por la sobrealimentación, con bajo valor nutricional, además de una actividad física insuficiente. También entienden que las acciones para combatir la obesidad resultaron ser incipientes o insuficientes. Para los niños, la obesidad implica insatisfacción con la imagen corporal y bullying escolar.

Conclusión: desde la perspectiva de los participantes, existe la necesidad de implementar acciones integradas entre los profesionales de la salud y la educación, los niños y los familiares, para prevenir y combatir la obesidad infantil; además de acciones gubernamentales para fortalecer políticas públicas que consideren la promoción de la salud y la prevención de lesiones en la población infantil.

DESCRIPTORES: Salud infantil. Familia. Obesidad pediátrica. Servicios de salud escolar. Educación. 


\section{INTRODUCTION}

Childhood obesity is considered a public health problem, and is associated with the onset of health problems such as cardiovascular disease, hypertension, dyslipidemia, type 2 diabetes mellitus, kidney problems, liver steatosis, cancer, mental suffering, and musculoskeletal problems, among other complications, in addition to the potential to deny many of the health benefits that contribute to increased life expectancy. ${ }^{1-3}$

Overweight and obesity already affected 41 million children under the age of five in 2014 , on the world scenario. However, under these conditions, more children live in low- and middle-income countries than in high-income countries. Many countries face the burden of malnutrition and rising rates of childhood obesity. Thus, as countries go through rapid socioeconomic and/or nutritional transitions, they also face a double burden in which inadequate nutrition and excessive weight gain coexist. ${ }^{3}$

In Brazil, this reality is visible in the child population, with consequences present both during this phase and in adult life, since an overweight child is more likely to become an obese adult. ${ }^{3}$ In addition, the quality of life of an obese child is lower when compared to that of eutrophic children, especially when evaluated in relation to social issues, ${ }^{4}$ since it can also affect the educational level.

In addition, obesity and related conditions influence the economy and burden a country's health systems and may increase. This is due to the need to invest economic resources to prevent and combat obesity. ${ }^{5}$ Preventive actions are more effective for the economy of the health systems, through primary care, to the detriment of cure at the secondary and tertiary levels. However, the various health problems developed in childhood can persist into adulthood, and cost more to the population. ${ }^{5}$

It is worth mentioning that some governmental approaches are required for preventing and treating obesity. In Brazil, the Health at School Program (Programa Saúde na Escola, PSE) is part of the public policies and aims at prevention, promotion and health care in the school environment, based on inter-sectoral actions, such as the promotion of a healthy diet and nutritional assessment. ${ }^{6}$

In the municipality of Cascavel, State of Paraná (PR), Brazil, the aforementioned research study with Nursing professionals working in the PSE reveals their concern with the occurrence of obesity in children and adolescents. ${ }^{7}$ In the wake of learning more about the childhood obesity phenomenon in this context, the aim was to understand the perspective of children, relatives and health and education professionals about childhood obesity.

\section{METHOD}

A qualitative, exploratory and descriptive research study. The inclusion criteria for children were the following: aged between six and 12 years old, classified as having childhood obesity by the nutritional assessment of the PSE, according to the Body Mass Index (BMI), and being enrolled in two public schools in the area covered by four primary health care units, in the municipality of Cascavel, PR, agreed upon with the PSE and chosen for the study, during the data collection period. For family members: being a parent or other primary caregiver of a child participating in the study. For health professionals: acting and developing PSE actions, in the four primary health care units of the study and/or with the schools attached to the PSE, in the municipality of Cascavel, PR. For education professionals: being an educator for children of the aforementioned age group; being a school manager or other professional acting directly or indirectly in preparing food for the schools participating in the study. Children who presented any physical or mental condition that made it impossible for them to participate in the interviews were excluded from the study, as well as family members identified as occasional caregivers, and health and education professionals who were on vacation or away from work due to special or medical leave. 
Data collection took place from April 2017 to March 2018, through semi-structured interviews, lasting approximately 30 minutes each. Obese children were identified to participate in the study and their families, based on the clinical and nutritional evaluation of the PSE, carried out by primary care health professionals. The initial explanation about the study, the invitation to participate and the scheduling of the interviews took place over the phone, using the registration data of each child under study at the PSE.

The contact with health and education professionals was in their respective workplaces; therefore, in the health unit and at school. Children and family members were interviewed at their homes; health professionals in the health unit; the education professionals, in the school. The interviews were conducted by three Scientific Initiation scholarship students, in the Institutional Program of Undergraduate Scientific Research Scholarship (Programa Institucional de Bolsas de Iniciação Científica, PIBIC) modality. One student interviewed children, another interviewed family members and the third interviewed professionals.

This research analyzed 39 participants: 13 children, 12 family members, seven health professionals (nurses, physicians, community health worker and social worker), seven education professionals (professors, director, supervisor, lunch cooks). The Free and Informed Assent Form (FIAF) was applied to the children with consent of the family members. For family members and professionals, the Free and Informed Consent Form (FICF) was signed after explaining the research and after obtaining the participant's consent.

The questions prepared for all participants had as their main focus the understanding and perspective on childhood obesity as well as the lifestyle habits of the children and family members, particularly regarding eating habits and physical activity, access, preparation and types of food consumed by the children; meal times and places, actions taken and future expectations to combat obesity, among other issues to achieve the study objective. It was also sought to know, together with the children, about satisfaction with their body image and how they feel about it.

Some playful resources (drawing, painting, clipping and collage) were used with the children to facilitate the answer to semi-structured questions. To identify the child's satisfaction with body image, the Scale of Silhouettes was used, adapted and validated for children and adults. ${ }^{8}$ This scale contains nine male and nine female figures, respectively, arranged in the order from the smallest to the largest silhouette. The children were instructed to choose the figure that most resembled the perspective they had of their own body and the one that represented the ideal body. If they identified the same silhouette, this meant they were satisfied with their body image. Otherwise, it meant dissatisfaction with the current body image.

The participants were identified with letters representing their profession, followed by ordinal numbers referring to the order of the interview. Letter $C$ refers to the child, $M$ to mother, $O$ to the other responsible; PSE to health professional, nurse ("Profissional da Saúde, Enfermeiro" in Portuguese), PSM to medical health professional ("Profissional da Saúde, Médico" in Portuguese), PSACS to health professional, community health agent ("Profissional da Saúde, Agente Comunitário de Saúde" in Portuguese); and PEP to professional education professor, among others, followed by an ordinal numbering referring to the order of the interview. Example: C1, M1...PSE1.

The analysis was performed using the thematic analysis technique. ${ }^{9}$ In the pre-analysis, a fluctuating and comprehensive reading of the set of interviews was carried out. Subsequently, an exhausting reading took place in order to organize the thematic units. In the exploration of the material, the contents of the thematic units were aggregated and classified to define the thematic categories of analysis, considering the main and common ideas. In the treatment of the obtained results and interpretation, it was possible to highlight the information obtained, and to observe the agreement and solidity of the thematic categories. Following each of the analysis stages, as directed by the analytical 
method, ${ }^{9}$ methodological rigor was respected. The repetition of information from the interviews, due to the phenomenon of theoretical saturation, allowed ending data collection.

\section{RESULTS}

Three categories were identified: Multifactoriality of childhood obesity; Body image by the child, by family members and bullying at school; Perspectives and actions associated with childhood obesity.

\section{Multifactoriality of childhood obesity}

Childhood obesity was linked to multiple conditions, mainly to the lifestyle habits of the children and family members, a priori to the eating habits. The eating habits presented low nutritional value. Breakfast was commonly ignored. The children rarely ate supper, with habits of greater intake of carbohydrates and fats to the detriment of vegetables and fruits in other meals, according to the testimonies of mothers and children: [...] He just eats rice and meat. When he comes back from school, sometimes I buy him some tidbit [...] rissoles, cheese balls (M3).

I didn't eat anything yesterday morning. [...] I eat rice, meat and soft drink. [...] in the afternoon I eat the school lunch. It was a cookie with milk. When I arrived [from school] I went to my grandmother's and ate an egg. Then, I went to my mom's cafeteria and ate a snack [...]. Sometimes I don't have dinner [...] (C7).

Some family members reported that they lived a childhood marked by difficult access to food, such as snacks, crackers, sweets, and chocolate, among others. Therefore, they did not limit the child to consuming them: On my day, we didn't have things to eat as it is now. So, I really did not felt like [...]. Now I let you eat if you feel like (M2).

The children had the autonomy to choose the location of the meals, which are often eaten in the living room or bedroom as well as allowing the use of electronics such as television, computer and cell phones. In addition, it was noted that the habits and behaviors of family members reflect what the child understands as right and appropriate: [...] grandma eats in the living room, grandpa and mother here in the kitchen and me in the bedroom (C8).

The maternal figure was the main responsible for the preparation of the main meals. Working mothers reported lack of time and unwillingness to prepare healthy food: [...] I go to work at night and there is no time for me to have dinner right, something different, a salad [...]. Ending up eating bread [...]. We don't regulate the quantity [...] (M1).

The school also offered foods rich in fats and carbohydrates. In view of this, the health professionals stressed out the need to pay attention to the quality of school food: [...] food... [at school] they have sausage, they have hamburgers, they have pizza. [...] it doesn't offer fruit. So, imagine at home [...] (PSE3). But the education professionals understood that food education was mainly the parents' responsibility: I think it's kind of complicated when it comes to the school doing something [...] it falls more to the family (PEP1).

There is media interference in the choice and food consumption of families and children, which requires family members to argue more about nutritious and healthy foods. There is also a demand to deal with possible tantrums: [...] there is no advertisement for rice that is attractive to children. Now, the child sees advertising of a packet of chips in the market and wants to buy (M5). He really likes fried salty [...]. When we go to the market, he goes crazy. You have to buy! (M3).

Childhood obesity has also been linked to insufficient practice of physical exercises/activities by the children, which are practiced, in their majority, at school, once a week, as a part of the school agenda. Therefore, performing other exercises/activities is not a habit during school hours. 
The children were sedentary and the families pointed out difficulties in inserting them in sports/physical activities due to lack of time and financial resources, linked to urban violence, whose parents did not allow children to play in the street. However, the parents were also sedentary and were overweight or obese: [...] we work at night, so during the day we have to rest. And you can't let them play on the street, it's very dangerous (M1); He's very sedentary, I can't get him out of the house to walk on the street. But I don't really like walking, either. I can't say it's just his fault, because mine too (M3); She has been referred to a nutritionist for two years, but cannot get an appointment. [...] she's not much of playing running, or anything, she prefers to play with doll house, little school, indoors. So she doesn't move much (O3); [...] usually, for the child or adolescent who is obese, in the family you already have a mother or father in the family who is obese (PSACS).

\section{Body image by the child, by family members and bullying at school}

The totality of the participating children registered a body image different from the one they would like to have, by applying the Scale of Silhouettes. Some family members disagreed, in their testimonies, that the children (according to their real body image) presented an obesity condition: I don't think she's obese, just a little full (01).

The children did not feel discomfort related to obesity in the relational processes established in the family environment. However, most of them had these feelings in the school environment because of the offensive verbal expressions by the peers, conditioning the feeling of injustice, sadness and low self-esteem by the children: [...] nobody likes to be fat. I don't even like being fat. [...] she [mother] tries to encourage me by saying that I'm beautiful. I don't think I'm beautiful (C1); I would like to be slim [...] so that nobody calls me fat (C2); Because there are people that call us fat, whale, killer whale. This is unfair [...]. Because at school they [class peers] call us fat (C3); [...] I can't stand being called fat anymore. I get sad! Ah, because they [class peers] keep calling me all sort of names (C4).

The child being victim of bullying had sadness and easy crying, and food consumption became a strategy to compensate for this feeling. Following or concomitant to this, the children showed less desire to exercise, started to isolate themselves, expressed a desire to change or to leave school and even not want to leave the house: [...] bullying, that children suffer, we see this here at school [...] this student he's very sad and cries, cries a lot, feels like the worst person in the world, when someone calls him fat [...] he's devastated [...] the parents have already come here to school, because he comes home crying (PEP1); I also don't want her to be suffering, because last year I already had to go there to talk to some children who called her fat and she came home crying (M9); [...] after they reach a certain weight they say: Ah, if my peers are like that with me I don't feel like leaving the house anymore, exercising, so I end up taking revenge of everything with food (PSM1); [...] they feel very embarrassed [...] they get nervous. There are some who no longer want to come to school, they want to change to another school [...] (PEP2).

\section{Comorbidities associated with childhood obesity}

The children expressed a desire for change related to weight and body image. On the other hand, the families indicated difficulties in adjusting the clothing and to insert the child into sports activities, whose rhythm of the child, when not respected, led to rejection of the activity. It is important to note that some family members claimed that the child was not in a condition of obesity: May $I$ look pretty. I want to change, to lose weight, for the better (C6); I have already tried to put him in the soccer school, he went for two months and he didn't want to because he couldn't stand running, so 
the teacher forced him and he cried. He didn't want to go any more at all. Exercising is difficult [...]. He's short, it's hard to find clothes because he wears an adult size (M3); [...] he's not obese, but he's chubby [...] he's normal, he sleeps well, he eats [...] (O1).

Some families had expectations on professional support to help them with care for obese children, such as professional guidance, access to specialists (nutritionist, psychologist, among others) and a greater offer of physical activity for children at school: I would like some guidance, take him to the nutritionist [...]. At school there should be more physical activity and at the clinic [health clinic] a referral to professionals, that would not take so long. Because if we talk, he doesn't listen. He thinks I'm bad. If someone else spoke, he might hear them (M6); I think there should be a psychologist in the schools and in the clinic [health clinic]. A lecture, a teaching for them at that age. Because, many times, what we pass on to them, they pass over, don't give much importance (M7).

The health assessments of children and adolescents were carried out by the PSE. When cases of obesity were identified in children up to five years old, the professionals scheduled appointments with the pediatrician at the basic health unit. When obese adolescents were identified, they were invited to participate in the Obesity Group in the basic unit, in which lectures were offered with a view to food reeducation. Only children and adolescents identified with morbid obesity and its problems were referred to the only nutritionist available in specialized care in the municipality: [...] the pediatrician [...] here at the unit she treats children up to five years old, because of the expressive number of children [...]. The Health at School Program [...] gives the referral and the nurse may be referring [to the nutritionist]. This year we did a job of calling the teenagers to the obesity group [...]. Only the [cases of] morbid obesity were sent to the nutritionist. [...] here we have diabetic children aged nine, ten years old, who have no control [...] (PSE3); [...] they are sent to see the nutritionist, but unfortunately not everyone who is referred goes (PSACS).

Thus, difficult access to the nutritionist in the municipality was identified. And when care was provided, it was difficult for the family members and the children to follow the prescribed menu, mainly due to the need to change their eating habits. Healthy eating was addressed at school, based on the food pyramid, in addition to offering physical activities, both inherent in the contents and activities of the teaching curriculum. However, there are insufficient actions to generate changes: [...] all the children that we referred last year [to the nutritionist] were still waiting in line. We have a nutritionist in the city just to serve the entire city [...] (PSM2); The nutritionist is the most difficult point [...] menu very difficult to follow or if the menu is good, the family does not adapt [...]. They eat very bad [...] one should educate the child together with the adult, which is all family upbringing [...] if the culture of the population doesn't change, there will be no point in having a healthy program, physical activity [...] (PSM1).

Health professionals suggested as strategies to combat obesity the presence of a physical educator in Primary Health Care (PHC) to work with the community, stimulate and provide access to exercise. The presence of professionals in training in this area who work in PHC and specialists such as a psychologist, nutritionist and endocrinologist in the health network, with easy access, to serve obese children and adolescents. [...] having an activity professional, a physical educator in the unit, but we don't have [...] (PSE2); We could have one more psychologist, with free access to identify these eating disorders; we could also have an endocrine to check this issue of metabolic diseases [...] also a nutritionist to guide us (PSE1). 


\section{DISCUSSION}

The results corroborate with the literature when they address the multi-factorial nature of childhood obesity as a disease ${ }^{1-2}$ and, although it has some relation with genetics, it is less expressive than lifestyle and cultural habits, such as inadequate food in quality and quantity, added to physical inactivity. ${ }^{3-10}$

When it comes to eating habits, breakfast is effective for weight control in childhood ${ }^{11}$ and favors the maintenance of a balanced diet. However, such a meal seemed to be ignored by the children interviewed, and it was possible to relate obesity to not having breakfast. ${ }^{11}$ In the other meals, there was an excessive consumption of processed foods by the children, with a high content of fats, sugars, sodium and high energy value, ${ }^{12}$ particularly at night. They replace basic and necessary foods with the option of exchanging for other foods of their preference, which favor obesity, one of the main risk factors for cardiovascular diseases in adulthood. ${ }^{13}$

There was no consumption of fruits and vegetables by the children in this study. This data corroborates with a national survey that verified a low consumption of these foods in the Brazilian dietary routine, in all age groups. Among children and adolescents, the mean consumption found is between $30 \%$ and $40 \%$, with a reduction in intake as age increases. In this sense, the low consumption of these foods can be linked to obesity, since they are effective for weight control and help to reduce the consumption of products with high caloric density. ${ }^{14}$

As for the excessive consumption of food, even for those considered healthy, similar results reveal that the child's weight gain is related to a daily caloric surplus of 70 to $160 \mathrm{kcal}$, according to the total energy needs. Therefore, the reduction of calories, linked to changes in eating habits and physical activity could be promising strategies for weight loss in the children. ${ }^{15}$

The parents' eating practices have an impact on the children's diets, especially with regard to eating foods considered unhealthy. In this sense, the behavior of the parents, when inappropriate, is a risk factor for overweight and obesity in children of preschool age, as identified by the data. ${ }^{16}$

The maternal figure is predominant in food preparation. However, due to other roles assumed by women in the capitalist production system, there is an overload that leads to the search for practicality, usually with the use of processed foods. Linked to this, the apathy of the parents regarding food education allows autonomy of unhealthy food choices by the children, favoring weight gain. This practice reinforces that the role of the guardians has been deviating, while children progressively achieve negative autonomy. ${ }^{17}$

The media encourages food errors with advertisements for low nutritional quality products, attractive to children. In these advertisements, the most common infraction is the use of children's characters, whose advertising benefits the sales of the product, taking advantage of the children's susceptibility. ${ }^{18}$ In this regard, research data on types of food shown in advertisements on Brazilian over-the-air television, during children's programming, point out that, of 126 hours of recorded food exposure on television channels, $13.8 \%$ were related to food products and, of these, $48.1 \%$ belong to the group of sugars and sweets. While only $1.1 \%$ referred to vegetables and legumes. ${ }^{18-19}$

The parents, in addition to being responsible for the food offered to their children at home, should be the main nutritional educators, since family eating habits influence children's eating behavior. ${ }^{20-21}$ However, neither the school nor the parents identify the necessary support for healthy choices for the children. Thus, the incentive for a balanced diet to reduce obesity cases ${ }^{20}$ arises from the shared efforts between parents and school.

Health education for children may come to enable them to recognize an adequate and healthy diet, in addition to identifying the reasons for unhealthy choices. Therefore, they can be integrated (the children) as protagonists in the change processes in terms of food, making them more autonomous 
in their choices and multipliers of the knowledge learned for their family members and other people around them. The school's role in including the family in this process is reinforced, as actions tend to be more effective if both share the same objective. ${ }^{16,20,22}$

As reasons for the insufficient practice of physical activities by the children in the current context, the presence of urban violence which affects the entire country ${ }^{23}$ is confirmed, added to the parents' financial difficulties to insert the children in other activities, besides those that already exist in the school. However, the family members' lack of commitment and adherence in the acquisition of healthy habits are notable solidifiers of childhood obesity. ${ }^{17}$

In addition to that, the mistaken perception of body image by the child or the denial of obesity by the families present themselves as a barrier to the necessary changes for a better quality of life and child health since, without identifying the problem, there are no active interventions ${ }^{24}$ It is noted that the denial of the child's overweight by the family members is influenced by beliefs such as: 'When you grow up you lose weight', 'A healthy child is a chubby child'. These beliefs prevent the perception of the problem and postpone the search for help with health professionals, as well as the adoption of necessary changes to the family lifestyle, which increase the risks to the child's health. ${ }^{24}$

As a result of obesity, the occurrence of bullying at school is confirmed, with consequences for the children's health, ${ }^{25}$ especially to mental health. One way of escaping the aggressors and inhibiting the act is for the child to seek the presence of an adult, ${ }^{26}$ being a condition not identified in the data, as the children's suffering seems little shared and or perceived, even by the families. Such fact leads to the need for a broader view of the families, health and education professionals regarding the presence of bullying in the school spaces. In particular, it reinforces the importance of the educators recognizing this practice and acting actively towards its extinction, ${ }^{24}$ when they seek support from health professionals for coping processes with children who are provoked or intimidated. ${ }^{25}$

Professional support as an expectation of the families to assist them in the problem of childhood obesity is already part of governmental programs, such as the PSE and the National School Feeding Program (Programa Nacional de Alimentação Escolar, PNAE). ${ }^{6,27}$ Among the PSE actions there is psychosocial evaluation, which favors prevention, fighting against bullying and nutritional evaluation, as well as of the promotion of healthy eating and of physical activity. ${ }^{6}$ The use of healthy and adequate foods at school is one of the guidelines of the PNAE. ${ }^{27}$

However, the successful implementation of all the actions of these programs is an urgent need, with comprehensive actions that promote physical activity and reduce the children's sedentary behaviors, with the promotion of healthy school environments, health education for children and inclusion of families. ${ }^{3}$ Above all, as greater offer of professionals in the health network, such as nutritionists, psychologists, physical educators, by the municipal health management, to cover all the actions necessary to put an end of childhood obesity. ${ }^{3}$

According to the PSE assessment, in all Brazilian states, ${ }^{28}$ it is verified that professional training to act in the actions of this program was little executed. ${ }^{7,28}$ It is important to note that this training contributes to the performance of prevention, promotion and health care activities in a joint manner, adding efforts and sharing the competences of each area. ${ }^{28}$ Therefore, it is recommended that professionals and local managers reflect on the obstacles that make it impossible to achieve all the objectives proposed by the program. ${ }^{7}$

And, as for the professional support to the families so that they can better act in the problem of obesity, research studies show that, in the United States, the performance of a multidisciplinary team, together with the participation of the family, was positive in the evaluation of a weekly program of practical and theoretical activities about food, physical exercise and emotional health, in the treatment and prevention of childhood obesity. ${ }^{29}$ 
In this study, it was identified that the families see unpreparedness in the school's physical educators to deal with obese children regarding the reception, encouragement and respect with physical limitations to carry out the activities that are important allies in the fight against obesity. These can be easier to manage than dietary changes. Therefore, the professionals in the field need to be prepared to work with this population, without forcing them to carry out activities at the same pace as non-obese children, to motivate them in the activity routine, respecting their limitations. ${ }^{30}$

In this research, professionals working with the PSE were interviewed; however, program managers and specialized care professionals, such as the nutrition service, were not included, so this is a limitation of the methodological design; in addition to being conducted in two schools. Therefore, it is suggested to expand the research design in future studies to better understand the phenomenon of overweight and, consequently, of childhood obesity.

\section{CONCLUSION}

From the perspective of the study participants, excessive eating, with a low nutritional value, at home and at school, and insufficient physical activity were the main factors for childhood obesity. The children were dissatisfied with their body images, in addition to being bullied at school. Actions to combat the condition of childhood obesity, by family members and health and school professionals, proved to be incipient or insufficient.

Based on the results, in addition to the implementation of all the PSE actions, the need is recommended for health professionals and educators to strengthen their guidelines to the children and their family members on healthy eating, appropriate sleep time, importance of breakfast, physical activity or active play in the children's daily routine and appropriate practice regarding screen entertainment. Furthermore, the availability of public community spaces for physical activities, conducted by physical educators, made available by the municipality, is required in order to aggregate people and encourage healthy lifestyles by the children and their families. Regular weight control can be one of those activities. In addition, it is important that the schools comply with the healthy nutritional guidelines for offering or selling food.

Finally, there is an evident need for integrated actions between health and education professionals, including children and family members, in order to plan and implement strategies to prevent and combat childhood obesity, anchored mainly in changing life habits. Actions such as those of the PSE and the PNAE demand governmental actions to strengthen public policies that consider health promotion and prevention of health problems in the child population.

\section{REFERENCES}

1. Lee EY, Yoon $\mathrm{KH}$. Epidemic obesity in children and adolescents: risk factors and prevention. Front Med. [Internet]. 2018 [cited 2018 Dec 01];12(6):658-66. Available from: https://doi.org/10.1007/ s11684-018-0640-1

2. Nehus E, Mitsnefes M. Childhood Obesity and the Metabolic Syndrome. Pediatr Clin North Am [Internet]. 2019 [cited 2019 Feb 10];66(1):31-43. Available from: https://doi.org/10.1016/j. pcl.2018.08.004

3. World Health Organisation. Report of the Commission on Ending Childhood Obesity. World Heal Organ. 2016 [cited 2018 Jul 15]; Available from: https://apps.who.int/ iris/bitstream/handle/10665/204176/9789241510066_eng.pdf;jsessionid=366ac $3 \mathrm{ff} 3 \mathrm{c} 7 \mathrm{cc} 2 \mathrm{a} 82 \mathrm{c} 83 \mathrm{f5f} 4 \mathrm{c} 8920952$ ? sequence $=1$ 
4. Cunha LM, Pantoja MS, Portella MB, Furlaneto IP, Lima AVM. Impacto negativo da obesidade sobre a qualidade de vida de crianças. RBONE [Internet]. 2018 [cited 2019 Aug 23];12(70):231-8. Available from: http://www.rbone.com.br/index.php/rbone/article/view/686

5. Dinh-Toi C, Nguyen TMN, Thien CD, Nguyen VTL, Khanh-Hoang N, Vo Truong NN, et al. An update on physical health and economic consequences of overweight and obesity. Diabetes \& Metabolic Syndrome [Internet]. 2018 [cited 2019 Aug 23];1095-1100. Available from: https://doi. org/10.1016/j.dsx.2018.05.004

6. Brasil. Ministério da Saúde. Cadernos de atenção básica. Saúde na escola. [Internet]. 2009 [cited $2020 \mathrm{Fev}$ 27] Available from: http://bvsms.saude.gov.br/bvs/publicacoes/cadernos_atencao_ basica_24.pdf

7. Baggio MA, Berres R, Penteado B, Gregolin S, Aikes S. Introduction of the School Health Program in the city of Cascavel, Paraná State: report of nurses. Rev Bras Enferm [Internet]. 2018 [cited 2019 Mar 01];71(Suppl 4):1631-9. Available from: https://doi.org/10.1590/0034-7167-2017-0188

8. Ferrari EP, Santos SCF, Maciel LA, Souza DS, Souza JMM, Cardoso FL. Adaptation and validation of silhouette scales for Brazilian children. Motricidade [Internet]. 2018 [cited 2020 Mar 3];14(Suppl I): 5-10. Available from: https://doi.org/10.6063/motricidade.16224

9. Minayo MSC, organizador. Pesquisa Social: teoria, método e criatividade. 34th ed. Petrópolis: Vozes; 2015.

10. Souza NP, Lira PIC, Fontbonne A, Pinto FCL, Cesse EÂP. (Mal)nutrition and the new epidemiological trend in a context of development and inequalities. Cien Saude Colet [Internet]. 2017 [cited 2018 Nov 12];22(7):2257-66. Available from: https://doi.org/10.1590/1413-81232017227.03042017

11. Pedraza DF, Silva FA, Melo NLS, Araujo EMN, Sousa CP da C. Estado nutricional e hábitos alimentares de escolares de Campina Grande, Paraíba, Brasil. Cien Saude Colet [Internet]. 2017 [cited 2018 Dec 10];22(2):469-77. Disponível em: https://doi.org/10.1590/141381232017222.26252015

12. Martins APB, Levy RB, Claro RM, Moubarac JC, Monteiro CA. Increased contribution of ultraprocessed food products in the Brazilian diet (1987-2009). Rev Saude Publica [Internet]. 2013 [cited 2018 Dec 10];47(4):656-65. Available from: https://doi.org/10.1590/S0034-8910.2013047004968

13. Barroso TA; Marins LB, Alves R, Gonçaves ACS; Barroso SG; Rocha, GS. Association of central obesity with the incidence of cardiovascular diseases and risk factors. Int J Cardiovasc Sci [Internet]. 2017 [cited 2019 Jan 20];30(5):416-24. Available from: https://doi.org/10.5935/23594802.20170073

14. Vieira Machado RH, Feferbaum R, Leone C. Fruit intake and obesity Fruit and vegetables consumption and obesity in Brazil. J Hum Growth Dev [Internet]. 2016 [cited 2018 Nov 06]; 26(2):243-52. Disponível em: https://doi.org/10.7322/jhgd.119293

15. Pereira HRC, Bobbio TG, Antonio MARGM, Barros Filho AAl. Childhood and adolescent obesity: how many extra calories are responsible for excess of weight? Rev Paul Pediatr [Internet]. 2013 [cited 2018 Sept 10];31(2):252-9. Available from: https://doi.org/10.1590/S0103-05822013000200018

16. Melo KM, Cruz ACP, Brito MFSF, Pinho L. Influence of parents' behavior during the meal and on overweight in childhood. Esc Anna Nery [Internet]. 2017 [cited 2018 Sept 10];21(4):e20170102. Available from: https://doi.org/10.1590/2177-9465-ean-2017-0102

17. Dornelles $A D$, Anton MC, Pizzinato A. O papel da sociedade e da família na assistência ao sobrepeso e à obesidade infantil: Percepção de trabalhadores da saúde em diferentes níveis de atenção. Saude Soc [Internet]. 2014 [cited 2018 Jul 01];23(4):1275-87. Available from: http:// www.scielo.br/pdf/sausoc/v23n4/0104-1290-sausoc-23-4-1275.pdf 
18. Britto SR, Viebig RF, Morimoto JM. Analysis of food advertisements on cable television directed to children based on the food guide for the Brazilian population and current legislation. Rev Nutr [Internet]. 2016 [cited 2018 Jul 10];9(5):721-729. Available from: https://doi.org/10.1590/167898652016000500010

19. Costa SMM, Horta PM, Santos LC dos. Analysis of television food advertising on children's programming on "free-to-air" broadcast stations in Brazil. Rev Bras Epidemiol [Internet]. 2013 [cited 2018 Jul 01];16(4):976-83. Available from: https://doi.org/10.1590/S1415-790X2013000400017

20. Albuquerque OMR, Martins AM, Modena CM, Campos HM. Public school students' perceptions of the environment and food available at the school: an emancipatory approach. Saude Soc [Internet]. 2014 [cited 2018 June 10];23(2):604-615. Available from: https://doi.org/10.1590/ S0104-12902014000200020

21. Melo KM, Cruz ACP, Brito MFSF, Pinho L. Influence of parents' behavior during the meal and on overweight in childhood. Esc Anna Nery [Internet]. 2017 [cited em 2019 Sept 04];21(4):e20170102. Available from: https://doi.org/10.1590/2177-9465-ean-2017-0102

22. Araujo AL, Ferreira VA, Neumann D, Miranda LS, Pires ISC. O impacto da educação alimentar e nutricional na prevenção do excesso de peso em escolares. Revista Brasileira de Obesidade Nutrição e Emagrecimento [Internet]. 2017 [acesso 2018 Nov 30];11(62):94-105. Disponível em: http://www.rbone.com.br/index.php/rbone/article/view/494

23. Santos NN, Santos CB. Impacto social da violência urbana. Rev FAESF [Internet]. 2019 [acesso 2019 Apr 29];3(1):33-44. Disponível em: http://faesfpi.com.br/revista/index.php/faesf/article/ view/78/68

24. Camargo APPM, Barros Filho AA, Antonio MARGM, Giglio JS. A não percepção da obesidade pode ser um obstáculo no papel das mães de cuidar de seus filhos. Cien Saude Colet [Internet]. 2013 [acesso 2018 Jul 02];18(2):323-33. Disponível em: https://doi.org/10.1590/S141381232013000200004

25. Ariza KJB, Castillo CVC. Bullying or intimidation at school: contributions from the evidence of research in nursing. Texto Contexto Enferm [Internet]. 2018 [cited 2019 Jul 30];27(4):e0400017. Available from: https://doi.org/10.1590/0104-07072018000400017

26. Borges F, Barreto MS, Reis P, Viera CS, Marcon SS. Perceptions and attitudes of children experiencing obesity. Rev Rede Enferm do Nord [Internet]. 2018 [cited 2018 Dec 10];19:e3261. Available from: https://doi.org/10.15253/2175-6783.2018193261

27. Brasil. Lei n 11.947 de 16 de junho de 2009: dispõe sobre o atendimento da alimentação escolar e do Programa Dinheiro Direto na Escola aos alunos da educação básica. Diário Oficial da União 2009; 17 jun. [acesso 2019 Mar 30]. Disponível em: http://www.planalto.gov.br/ccivil_03/_Ato20072010/2009/Lei/L11947.htm

28. Machado MFAS, Gubert FA, Gomes AP, Meyer FV, Sampaio YPCC, Dias MSA et al. The health school programme: a health promotion strategyin primary care in Brazil. J Hum Growth Dev [Internet]. 2015 [cited 2018 Dec 01];25(3):307-12. Available from: https://doi.org/10.7322/jhgd.96709

29. Moxley E, Habtzghi D, Klinkhamer N, Wang H, Donnelly S, Dykhuizen J. Prevention and treatment of pediatric obesity: a strategy involving children, adolescents and the family for improved body composition. J Pediatr Nurs [Internet]. 2019 [cited 2019 Feb 28];45:13-9. Available from: https:// doi.org/10.1016/j.pedn.2018.12.010

30. Fisberg M, Maximino P, Kain J, Kovalskys I. Obesogenic environment-intervention opportunities. J Pediatr [Internet]. 2016 [cited 2018 Dec 10];92(3):S30-9. Available from: https://doi.org/10.1016/j. jped.2016.02.007 


\section{NOTES}

\section{ORIGIN OF THE ARTICLE}

Article extracted from the project - Addressing childhood-youth obesity in elementary schools, by the Group of Research on Maternal-Child Nursing, Universidade Estadual do Oeste do Paraná, which gathers data from projects of the Programa Institucional de Bolsas de Iniciação Científica, referring to the 2017-2018 period.

\section{CONTRIBUTION OF AUTHORITY}

Study design: Baggio MA, Alves KR, Cavalheiro RF, Matias L, Machineski GG, Caldeira S.

Data collection: Alves KR, Cavalheiro RF, Matias L.

Data analysis and interpretation: Baggio MA, Alves KR, Cavalheiro RF, Matias L.

Discussion of the results: Baggio MA, Alves KR, Cavalheiro RF, Matias L, Hirano AR.

Writing and/or critical review of content: Baggio MA, Machineski GG, Caldeira S, Hirano AR.

Review and final approval of the final version: Baggio MA.

\section{ACKNOWLEDGMENT}

To the study participants, who welcomed the researchers in their homes and in their workplaces.

\section{FUNDING INFORMATION}

Fundação Araucária de Apoio ao Desenvolvimento Científico e Tecnológico do Estado do Paraná. Call Edict 09/2016, of the Institutional Program for Basic and Applied Research (Pesquisa Básica y Avanzada, PBA), agreement No. 003/2017.

\section{APPROVAL OF ETHICS COMMITTEE IN RESEARCH}

Approved by the Research Ethics Committee of the Universidade Estadual do Oeste do Paraná under opinion No. 1,872,666; CAAE 60942716.8.0000.0107.

\section{CONFLICT OF INTEREST}

There is no conflict of interest.

\section{EDITORS}

Associated Editors: Selma Regina de Andrade, Gisele Cristina Manfrini, Melissa Orlandi Honório Locks, Monica Motta Lino

Editor-in-chief: Roberta Costa

\section{HISTORICAL}

Received: November 29, 2019.

Approved: April 30, 2020.

\section{CORRESPONDING AUTHOR}

Maria Aparecida Baggio

mariabaggio@yahoo.com.br 